\title{
Ribonuclease Activity of Human Cerebrospinal Fluid
}

\author{
E. Z. RABIN, V WEINBERGER AND B. TATTRIF
}

SUMMARY: The ribonuclease activity of cerebrospinal fluid of 219 patients was studied. The normal level was 269 \pm 95 units $/ \mathrm{ml}$. Consistent elevations above 550 units/ml were found in. I Chronic cerebrovascular disease, 2 Spinal cord compression; 3. Tumors. The molecular weights of the ribonucleases in the cerebrospinal fluid are approximatel 33,$000 ; 21,000$ and 15,000 , the major species is the one with $m w$. 33,000 .

RÉSUMÉ: L'activité de la ribonucléase du liquide céphalorachidien de 219 patients fut étudiée Le niveau normal est de $269 \pm 95$ unités/ml. Des élévations constantes au-dessus de 550 unités/ml furent trouvées dans. l) la maladie cérébro-vasculaire chronique; 2 ) la compression de la moëlle épinière; 3) les tumeurs. Les poids moléculaires des ribonucléases dans le liquide céphalo-rachidien sont approximativement de l'ordre de 33,000: 21,000 et 15,000: la principale molécule a un poids moléculaire de 33,000

Quoique l'augmentation de l'activité
Although the increase in the CSF ribonuclease activity is not disease specific, the measurement has provided corroborative help in cases when the CSF protein is normal.

The increase in CSF RNAase is not due to red or white blood cells and the immunologic data suggest that the CSF enzyme activity is derived from the blood stream Further studies are necessary to rule out a nerve cell origin of the CSF ribonuclease activity

de la ribonucléase dans le LCR n'e'st pas spécifique à une maladie, cette mesure a fourni une aide supplémentaire dans le's cas où les protéines du LCR sont normales.

L'augmentation de RNAase dans le LCR n'est pas dîe aux globules blancs ou rouges et les données immunologiques nous portent à croire que l'activité enzymatique du LCR est dérivée de la circulation sanguine D'autres études sont nécessaires pour prouver une origine à partir des cellules nerveruses de l'activité de la ribonucléase du LCR.
From the Montreal General Hospital, McGill University, Montreal, Quebec and Division of Nephrology, Ottawa Civic Hospital, 1053 Carling Avenue, Ottawa, Ontario, Canada.

Reprint requests to Dr. E. Z. Rabin, Division of Nephrology, Ottawa Civic Hospital, 1053 Carling Avenue, Ottawa, Ontario KIY 4E9, Canada.

\section{INTROIDUC'TION}

Since 1956 investigators have studied the levels of cerebrospinal (CSF) fluid enzymes in patients with and without neurological disease (Bien, 1968; Fleisher, Wakim and Goldstein, 1957: Hathaway, Berrett and Hunter, 1971; Herschkowitz and Cummings, 1964; Jakoby and Jakoby, 1958; Johnson and Domino. 1965; Kulhanek and Kableacova, 1964; Lisak and Craig, 1967: Mason and Roberts-Thomson, 1974: Rinne and Riekkinen, 1968; Schapira, 1962; Wakim and Fleisher, 1956; Wolintz et al., 1969; Wroblewski, Decker and Wroblewski, 1957). Their work indicates that the following mechanisms underlie the changes in the amounts of the enzymes in the CSF: 1) necrosis of tissue; 2) cells in the fluid i.e., red cells, white cells or tumor cells, and 3) disruption of the blood-brainbarrier. Because any or all of the above factors may be present in different neurological diseases, the changes in the levels of activity of such enyzmes as CPK, LDH, SGOT, aldolases, lysozyme, choloinesterase, and ribonuclease (RNAase) may be similar in demyelination, tumor, vascular disease, inflammation, atrophy and hemorrhage. The assays, therefore, may not be suitable for diagnostic purposes on a routine basis. A major exception has been a report (Hathaway, Berrett and Hunter, 1971) which suggests that CSF adenosine-5'-triphosphatase is markedly elevated in cerebrovascular disease. Since the levels of this enzyme are only minimally increased in inflammatory and demyelinating diseases, their results suggest some specificity in this diagnosis.

In 1969 Bien reported that RNAase level in the CSF is elevated in cerebrovascular disease and in an 
ill defined group of "other diseases" Coincidentally, the work in our laboratory has centered on the isolation and purification of ribonucleases from normal human urine (Rabin and Weinberger, 1975). During the course of our studies we found that ribonuclease activity was detectable in the CSF. Our preliminary investigations indicated that significant elevations of CSF RNAase occurred in chronic cerebrovascular disease and we proceeded to study the ribonuclease activity of the CSF in 219 patients. Our studies of CSF RNAase in patients with and without neurological disease form the basis of this report.

\section{MATERIALS AND METHODS}

RNAase assays: The assays were performed according to the method of Zimmerman and Sandeen (1965) as modified by Fink, Adam and Skoog (1971) and by Rabin and Weinberger (1975). The activity of the RNAase was measured by following the rate of release of acidsoluble material from a synthetic RNA polymer Poly C. One unit of enzyme was defined as the amount of enzyme required to release 1.0 O.D.278 unit of acid soluble material from Poly $\mathrm{C}$ in five minutes at $37^{\circ} \mathrm{C}$ under the assay conditions. A time course was always performed to ensure that measurements were made from the linear part of the curve.

Assays of serum and/or plasma were performed in the same manner as described above. Dilutions of serum were $1: 20$ to $1: 40$.

Cerebrospinal fluid protein values were obtained from the hospital charts of patients studied. The total protein was measured by the standard turbidometric method used in the clinical chemistry laboratory of the Montreal General Hospital (Schriever and Gambino, 1965).

The first $5 \mathrm{ml}$ of CSF obtained by lumbar puncture done for routine diagnostic testing, myelography or pneumoencephalography were used for assay. Samples were kept at $8^{\circ} \mathrm{C}$ prior to assay. Both centrifuged and uncentrifuged samples were assayed.

Immunological Studies. Purified human urinary ribonuclease was mixed with complete Freund's adjuvant. Five mg. were injected into rabbits three times at intervals of three weeks. Three weeks after the last injection the animals were exsanguinated and the antiserum was fractionated with ammonium sulphate in the standard manner in order to obtain the gamma-globulin (Fuchs et al., 1969). Normal rabbit serum was treated in an identical manner for control experiments. The antiserum was used to study samples of concentrated CSF by double diffusion ge! and immunoelectrophoretic techniques (Ouchterlony, 1964).

Studies with Cerebrospinal Fluid. Five hundred $\mathrm{ml}$ of CSF were obtained aseptically from a patient who had undergone pituitary surgery. The fluid was obtained postoperatively during an uneventful recovery period. The fluid was clear and colorless and contained an RNAase activity of 1850 units $/ \mathrm{ml}$. The CSF was dialyzed against KPB $0.01 \mathrm{M} \mathrm{pH} \mathrm{6.5,} \mathrm{concentrated} \mathrm{against}$ Carbowax 6000 and dialyzed exhaustively against $0.1 \mathrm{M}$ acetic acid/ $\mathrm{Na}$ acetate buffer $\mathrm{pH} 4.7$. The resultant solution was brought to $50 \%$ ammonium sulphate saturation to precipitate the albumin. After centrifugation the supernatant was dialyzed against $0.05 \mathrm{M} \mathrm{KPB} \mathrm{pH} 6.5$ and then concentrated to $3.4 \mathrm{ml}$ yielding a CSF solution with RNAase activity of 270,000 units $/ \mathrm{ml}$. This solution was used for the double diffusion and immunoelectrophoresis studies.

Sephadex Gel Filtration Studies. Fifty millilitres of CSF obtained by pooling 20 normal samples were concentrated against Carbowax 6000. A fraction of the concentrate was subjected to Sephadex G-100 gel filtration with appropriate markers in order to determine the molecular weight of the CSF RNAase activity (Andrews, 1965). Similarly, a sample of uremic serum was studied by the identical Sephadex G-100 filtration method.

Patients Studied. The diagnoses assigned to patients were checked by a careful study of hospital charts and by detailed discussions with the neurologists and neurosurgeons of the Montreal General Hospital. The diagnosis of acute vascular disease was made in patients who presented for the first time with a cerebrovascular episode. No prior history of neurological symptoms was present. All the cases were embolic or thrombotic and in most instances made excellent recoveries. The diagnosis of chronic vascular disease was made in those patients who had a previous history of an embolic or thrombotic episode or had a history of transient ischemic attacks. All patients in the study were seen by at least one neurologist, and in many cases the patients were under the direct care of the Neurological service at the Montreal General Hospital.

Patients in the anoxia group were admitted to hospital in states of confusion, stupor, or coma. The arterial $\mathrm{pO}_{2}$ was less than $60 \mathrm{~mm}$. $\mathrm{Hg}$. and the clinical diagnosis was usually chronic pulmonary disease with a superimposed acute pulmonary infection. Because of the mental state of the patient the neurological service was consulted.

\section{RESULTS}

The assays. The degradation of Poly $\mathrm{C}$ by samples of serum and cerebrospinal fluid was followed by time courses carried out for a minimum of 20 minutes and as long as 120 minutes. Samples with high and low and intermediate activities were studied and it was found that the rate of release of acid soluble material was proportional to the amount CSF added to the incubation mixture. For assays of CSF a 1:10 dilution was sufficient for almost all samples.

Storage of Samples. The CSF and serum ribonuclease activities remained unchanged for at least one month when stored in solution at $8^{\circ} \mathrm{C}$. The activity appeared stable at room temperature over several days.

CSF RNAase. The mean value of CSF RNAase in normal patients was found to be $269 \pm 95$ units $/ \mathrm{ml}$. Red blood cells and/or white blood cells contributed very little RNAase activity. Three ml. of packed washed red blood cells which were lysed and subsequently assayed for activity, 
yielded less than 25 units of RNAase. A preparation of granulocytes yielded only 1.0 unit per $4.8 \mathrm{x}$ $10^{5}$ cells. Therefore, the amount of RNAase which can be contributed to the CSF by cellular elements of the blood is negligible.

The serum level of RNAase activity of a group of normal individuals aged 17-74 was found to vary from $690-2880$ units $/ \mathrm{ml}$. In all of these individuals the BUN was less than $20 \mathrm{mg}$. \%.

Table I and figure 1 summarize the levels of CSF RNAase in patients with various neurological disease states. Consistent and marked elevations of CSF RNAase above 550 units $/ \mathrm{ml}$. occur in: 1) chronic cerebrovascular disease: 2) certain cases of dementia and atrophy: 3) compression myelopathy due to disc, tumor and lumbar spinal stenosis; 4) tumors; 5) chronic hypoxemia $\left(\mathrm{pO}_{2}<60 \mathrm{~mm}\right.$. Hg.) and 6) spinocerebellar degeneration.

One patient with seizures had a high CSF RNAase level: the cause of the seizures was thought to be vascular. One of seven patients with

TABLE I. CSF Ribonuclease units/m1

\section{IABLE I. CSF Ribonuclease units/mi \\ Normal \\ Psychiatric \\ Acute alcoholic encephalopathy \\ Bacterial meningitis (acute) \\ Chronic hypoxemia \\ Vascular disease
a. acute (lst episode)
b. chronic
c. with alcoholism
d. vasculitis

Dementia

Herpes simplex encephalitis

Spinocerebellar degeneration

Tumor

\section{Number} 33

10

35

Disc disease

a. no previous myelogram

(no compression)

b. previous myelogram

(no compression)

c. cord compression

Lumbar spinal stenosis

Demyelinating disease

Seizures-Idiopathic

Post-Traumatic

Miscellaneous

a. Guillain Barre

b. Barbiturate overdose

c. Spinal artery thrombosis (acute)

d. Peripheral neuropathy

e. Pituitary tumor

f. Vincristine neuropathy
8

4

2

9

1

18

1

3

5

Units/m1

$269 \pm 95$

$270 \pm 65$

$380 \pm 84$

$477 \pm 102$

$678 \pm 279$

$361 \pm 86$

$920 \pm 319$

1032

$823 \pm 319$

$640 \pm 354$

1562

$873 \pm 221$

$972 \pm 279$

$354 \pm 169$

$664 \pm 132$

$1090 \pm 6$

3

7

8

6

$781 \pm 35$

$407 \pm 112$

$394 \pm 157$

$362 \pm 140$

$461 \pm 95$

$756 \pm 356$

273

428

502

511 multiple sclerosis was found to have an abnormal high CSF RNAase level. The measurement was made within three months of the onset of an acute and widespread attack of the disease.

Patients with psychiatric disease and no objective evidence of neurological disease had normal values. Minimal elevations $(<500$ $\mathrm{U} / \mathrm{ml}$ ) of CSF RNAase can occur in demyelination, seizures, meningitis, peripheral neuropathy, acute subarachnoid hemorrhage, and uncomplicated disc disease. Elevations of CSF RNAase to levels below 550 units/ml were also seen in acute cerebrovascular disease. In one patient with a level of 225 units $/ \mathrm{ml}$ death occurred due to a pontine infarct.

Figure 2 shows the relationship between the CSF RN Aase levels and CSF total proteins in 126 patients. There was no specific measurement of albumin or globulin in the CSF since the method used for measurement of protein was a turbidometric one. It is clear that patients with neurological disease may have elevated CSF RNAase levels in the presence of normal total CSF protein levels. This dissociation between CSF RNAase and CSF total protein is not related to any particular disease.

Sephadex Gel Filtration Studies. The molecular weights of ribonuclease-enzyme activities were investigated in the CSF and in uremic serum. Figure 3 shows the results of Sephadex G-100 chromatography of CSF RNAase. Three distinct peaks are seen with molecular weights of $33.000,21,000$ and 15,000 . The bulk of the activity is in the 33,000 molecular weight peak. Chromatography of uremic serum in the same system shows two major peaks at molecular weights 33,000 and 18,000 (Fig. 4). It is possible that there are peaks at 21,000 and 15,000 but the resolution in this system is not adequate for the demonstration of these proteins.

Immunological Studies. Figure 5 shows the results of the immunological studies carried out with the concentrated CSF solution. The CSF reacts with the rabbit antiserum 


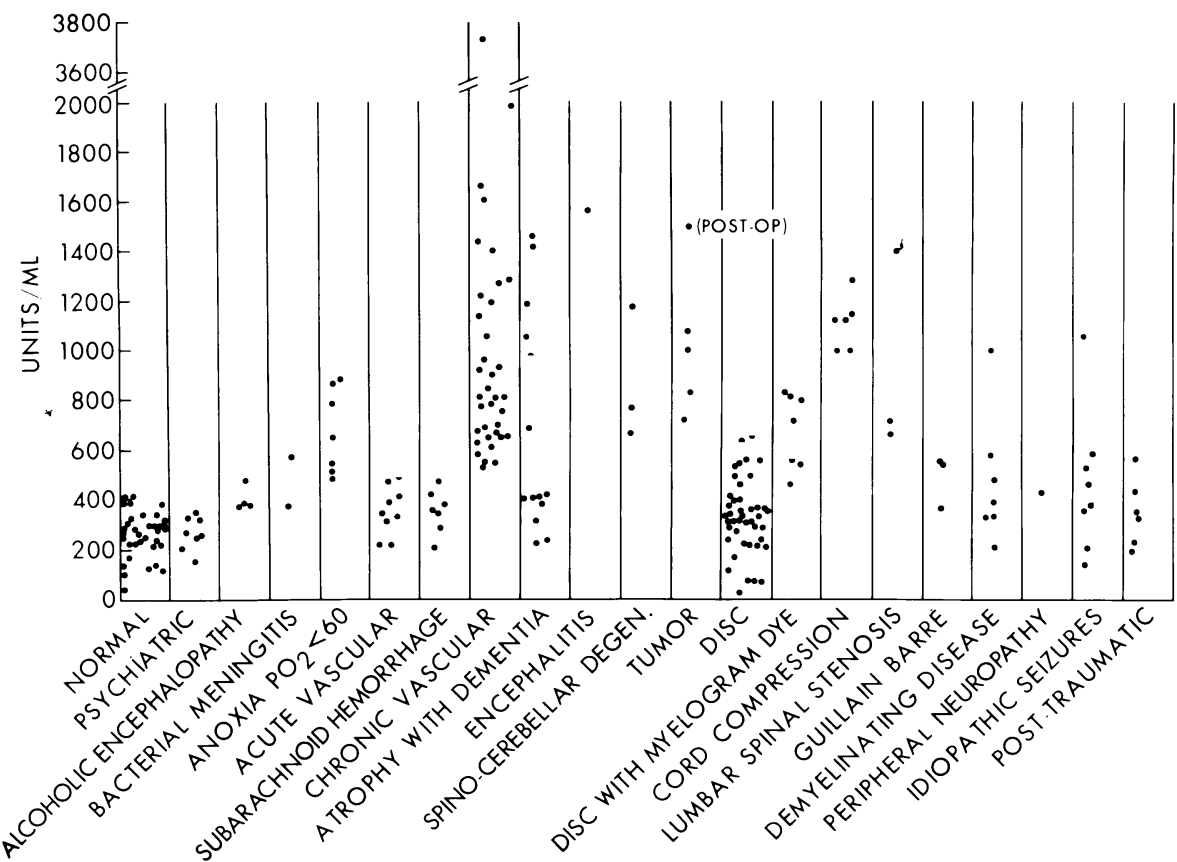

Figure 1-The ribonuclease activity of human cerebrospinal fluid in normal people and patients with psychiatric and neurological disease.

which contains antibody against human urinary ribonuclease. The double diffusion gel experiment demonstrated that the native human urinary RNAase and the antigen in the CSF were identical. The immunoelectrophoretic studies also demonstrated that the native human urinary RNAase and the antigen in the CSF produce similar reactions as the migration of the purified RNAase and the CSF antigen are identical. This implies that the CSF RNAase and the urinary RNAase are chemically the same.

We investigated the relation between the serum and CSF RNAase to determine if the CSF RNAase increased non-specifically with serum RNAase elevations. Statistical analysis demonstrated that there was no relationship. However, patients with renal failure on chronic hemodialysis, with high levels of serum RNAase $(8,000-35,000$ units $/ \mathrm{ml}$ ) and who did not have neurological disease had mild elevations of CSF RNAase, as high as 700 units $/ \mathrm{ml}$. Thus, increases in CSF RNAase may occur non-specifically in patients with chronic renal failure.

The serum/CSF RNAase ratio was examined in our patients and it was found that normal individuals without neurological disease had ratios which varied from 4.9:1-20:1. In patients with chronic cerebrovascular disease, tumor, cord compression, spinocerebellar degeneration and lumbar spinal stenosis the ratio was consistently less than $4: 1$. The usefulness of the ratio may be limited to patients with normal renal function since patients with renal failure have high levels of serum RNAase (greater than 3,000 units $/ \mathrm{ml}$ ). The high serum levels will artificially elevate ratios even with abnormally elevated CSF levels. The ratios in patients undergoing dialysis without neurological disease were found to be 12.8-23.6/1 and therefore tripling the CSF RNAase level in these patients the ratio would still fall within the range of normal.

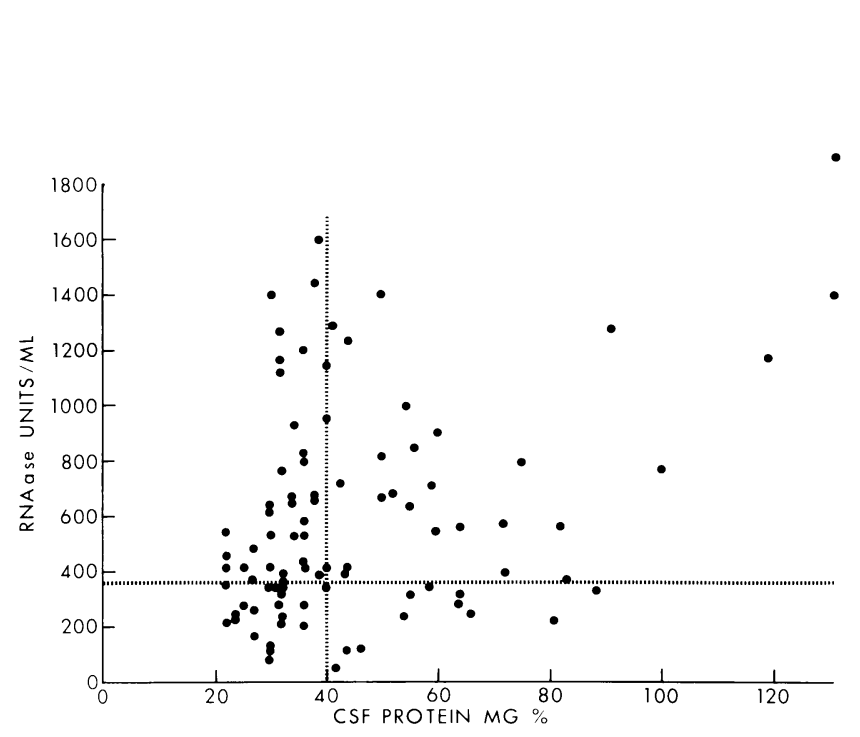

Figure 2-Relationship between cerebrospinal fluid ribonuclease activity and total protein.

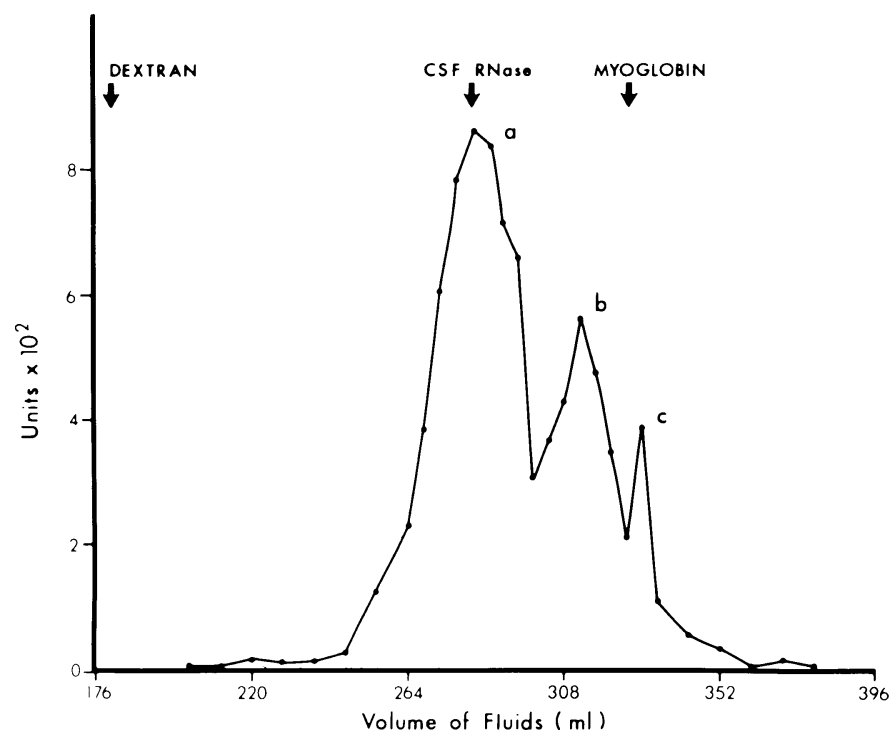

Figure 3-Sephadex G-100 Chromatography of normal human cerebrospinal fluid. Three peaks of activity with m.w. of $33,000,21,000$ and 15,000 are seen. 


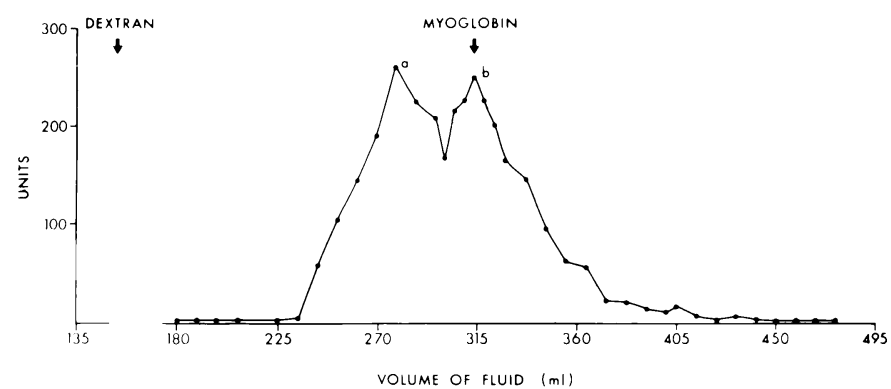

Figur' 4-Sephadex G-100 Chromatography of uremic serum. Two major peaks of m.w 33,000 and 18,000 are seen. A shoulder with m.w 21,000 is also apparent.

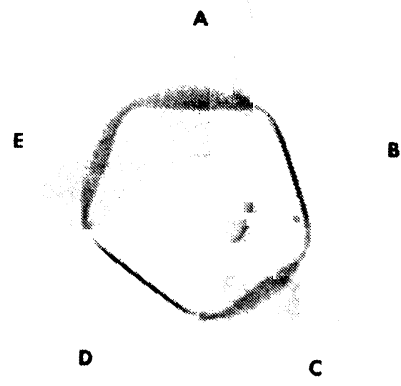

Figure 5-Gel Diffusion using antibody against purified human urinary ribonuclease. Antiserum in centre well Concentrated CSF (see methods) in wells B and D and purified human ribonuclease (markers) in 1 cells $A$. ( and $E$.

\section{DISCUSSION}

The results of this study demonstrated that the CSF contains ribonuclease activity and a major component of that activity was due to an enzyme of m.w. 33,000. Furthermore, the CSF contains a protein which reacts with rabbit antibody to human urinary ribonuclease. The ribonuclease used to induce this antibody was an enzyme-protein of m.w. 33,000 isolated from human urine. The immunological studies (double diffusion and immunoelectrophoresis) indicated that the antigen in CSF and the human urinary ribonuclease were identical. The data presented also demonstrated a ribonuclease activity in uremic serum of m.w. 33,000. Schmukler. Jewett and Levy (1975) have demonstrated the existence of a ribonuclease in human plasma and this enzyme had a molecular weight of approximately 32,000 and had a marked affinity for Poly C. Reddi (1975) has shown the presence of a Poly C-avid ribonuclease in normal human serum with properties similar to serum enzyme described by Schmukler et al. (1975) and to the urinary enzyme described by Rabin and Weinberger (1975). We have also shown that uremic serum contains an RNAase (m.w. 33,000) antigen which was immunologically identical to the purified human urinary ribonuclease (Rabin, Weinberger and Tattrie, 1976). We concluded that the RNAase m.w. 33,000 in the cerebrospinal fluid was probably derived from the blood stream.
The tissue source of this RNAase remains unknown.

The RNAase has an isoelectric point of $3.7 \pm 0.2$ and a molecular weight of 33.000 . The enzyme is slightly more positively charged than albumin $\left(P_{l}=4.7\right)$ and is one half the size. One could postulate that the enzyme would have an easier time than albumin passing from the blood stream into the CSF. (The normal serum/CSF ratio for albumin is $230 / 1$ whereas for RNAase activity it is 4.9-20/1). If that assumption is correct then one would expect increased RNAase in the CSF in tumors (Chou, Aust, Moore and Peyton, 1951) and in hypercapnia (Hochwald and Malhan, 1973) since the increased permeability of the blood-brain-barrier to albumin has been demonstrated in these conditions. Our clinical data showed that CSF RNAase was consistently increased in these situations.

The consistent elevations of CSF RNAase in compression myelopathy may be due to lack of protein removal and absorption. This mechanism has been documented by Sweet et al. (1954) to explain high CSF albumin levels in this clinical situation.

A major observation in this study was the finding of consistently high levels of CSF RNAase in chronic cerebrovascular disease. This confirms the findings of Bien (1968). We can only offer a speculative explanation for the mechanism. If the ribonuclease activity in the CSF is from the blood stream only and if the passage of the RNAase from the blood into the CSF is controlled by a barrier similar to albumin. one would have to postulate that the increase in CSF RNAase is due to a disruption in the normal bloodbrain-CSF barrier.

Experimentally, acute anoxia of the brain due to acute vascular occlusion has been shown to be unassociated with disturbances in the blood-brain-barrier However, the same investigators report leakage of protein in the more prolonged experiments during chronic anoxia (Olsson, Crowell and Klatzo, 1971; Hossman and Olsson, 1971: Hossman and Kleinhues, 1973: O'Brien. Jordan and Waltz, 1974). In chronic cerebrovascular disease some degree of anoxia may exist and lead to impairment of the blood-brainbarrier.

The mechanism by which the CSF RNAase is elevated in patients with dementia is unknown. Possibly some of these patients represent examples of cerebrovascular disease. Atrophy is not a cause of elevated enzyme levels. Normal CSF RNAase values were found in this condition.

Another mechanism which may play a role in the elevation of CSF $\mathrm{RNAase}$ is the release of a ribonuclease from damaged nerve cells. However, no one has demonstrated the presence of a poly $\mathrm{C}$-avid in human nervous tissue which could be implicated. It is possible that necrosis of cells leads to the liberation of such an enzyme activity. Patients with Guillain-Barre disease, SSPE, 
multiple sclerosis, peripheral neuritis, post-traumatic neurologic syndromes, acute subarachnoid hemorrhage, and acute bacterial meningitis showed only minimally elevated CSF RNAase levels (less than 500 units $/ \mathrm{ml}$ ). Factors other than damage to nerve cells must be considered in the pathogenesis of raised levels of CSF RNAase. The factors involved may include the duration and diffuseness of the pathological process, as well as the precise etiological agent.

The data presented also indicated that abnormalities in CSF RNAase were detected when the CSF protein values were in the normal range. The measurement of CSF RNAase may be useful when the CSF protein is normal. In our hands the enzyme measurement provided collaborative help in this clinical situation. We have not encountered the CSF RNAase abnormally elevated in a normal person.

This study corroborates to some extent the findings of Bien (1968). Although elevation of CSF RNAase is not disease specific, it appears to have some usefulness, particularly when the CSF protein is normal. We are radiolabelling the purified human urinary RNAase so that it can be injected into animals and human test subjects to determine its movement across the blood-brain-barrier.

\section{ACKNOWLEDGMENTS}

The authors thank Miss Ann Dougherty, Miss Norma Rocheleau and Miss Ilda Carvalho for secretarial assistance and the Medical Research Council for financial support through Grant number MA 4031.

\section{REFERENCES}

ANDREWS, P (1965). The gel filtration behaviour of proteins related to their molecular weight over a wide range. Biochem. J. 96: 595-606.

BIEN, A. (1968). Ribonuclease activity of the cerebrospinal fluid in neurological diseases. Neur Neurochir. Pol. 18: 479-483.

CHOU, S. N., AUST, J. B., MOORE, G. E. and PEYTON, W. T (1951). Radioactive iodinated serum albumin as tracer agent for diagnosis and localizing intracranial lesions. Proc. Soc. Exp. Biol. 77: 193.
FINK, K., ADAM, W S. and SKOOG, W (1971). Serum ribonuclease in multiple myeloma. Amer J. Med. 50: 450-457

FLEISHER, G. A., WAKIM, K. G. and GOLDSTEIN, N P. (1957). Glutamicoxaloacetic transaminase, and lactic dehydrogenase in serum and cerebrospinal fluid of patients with neurologic disorders. Mayo Clin. Proc. 32: 188-197

FUCHS, S., CAUTRECASAS, P., ONTJES, D. S. and ANFINSEN, C. B. (1969). Correlation between the antigenic and catalytic properties of staphylococcal nuclease. J Biol. Chem. 244: 943-950.

HATHAWAY, J A., BERRETT, C. R. and HUNTER, D. T (1971). Adenosine-5' triphosphatase activity in cerebrospinal fluid. Clin. Chem. 17- 658 .

HERSCHKOWITZ, N and CUMMINGS, J. N. (1964). Creatine kinase in cerebrospinal fluid. J. Neurol. Neurosurg. Psychiat. 27. 247-250.

HOCHWALD, G. M. and MALHAN, A. (1973). Effect of hypercapnia on CSF turnover and blood-brain barrier to protein. Arch. of Neurol. 28: 150-155.

HOSSMAN, K. A. and KLEINHUES, $P$ (1973). Reversibility of ischemic brain damage. Arch. of Neur. 29.375-384.

HOSSMAN, K. A. and OLSSON, Y (1971). The effect of transient cerebral ischemia on the vascular permeability to protein tracers. Acta Neuropathol. 18: 103-112.

HOSSMAN, K. A. and OLSSON, Y (1971). Influence of ischemia on the passage of protein tracers across capillaries in certain blood-brain barrier injuries. Acta. Neuropathol. 18: 113-122.

JAKOBY, R. K. and JAKOBY, W B. (1958). Lactic dehydrogenase of cerebrovascular disease and brain tumor J. Neurosurg. 15: 45-51.

JOHNSON, S. and DOMINO, E. F. (1965). Cholinergic enzymatic activity of cerebrospinal fluid of patients with various neurological diseases. Clin. Chim. Acta. 35: 421-428.

KULHANEK, V and KABELACOVA, M. (1964). Aldolase activity in cerebrospinal fluid. Clin. Chim. Acta. 10: 27-33.

LISAK, R. P and CRAIG F A. (1965). Lack of diagnostic value of creatine phosphokinase assay in spinal fluid. JAMA 199: 750-751.

MASON D. Y and ROBERTS-THOMSON, $P$ (1974). Spinal fluid lysozyme in diagnosis of central nervous system tumors. Lancet 2: 952-953.

O'BRIEN, M. D., JORDAN, M. M. and WALTZ, A. G. (1974). Ischemic cerebral edema and the blood-brain barrier. Arch. of Neurol. 30: 461-465.

OLSSON, Y, CROWELL, R. M. and KLATZO, I. (1971). Blood-brain barrier to protein tracers in focal cerebral ischemia and infarction caused by occlusion of the middle cerebral artery Acta. Neuropathol. 18: 89-102.

OUCHTERLONY, O. (1964). Gel diffusion techniques. In Immunological Methods. Ed. by J. F. Ackroyd. F A. Davis Co., $55-78$

RABIN, E. Z. and WEINBERGER, V. (1975). The isolation, purification and properties of a ribonuclease from normal human urine. Biochem. Med. 14: 1-11

RABIN, E. Z., WEINBERGER, $\mathrm{V}$ and TATTRIE, B. (1976). Ribonuclease activity in human serum, cerebrospinal fluid and urine. Manuscript submitted for publication.

REDDI, K. K. (1975). Nature and possible origin of serum ribonuclease. Biochem. Biophys. Res. Comm. 65: 110-118.

RINNE, U K. and RIEKKINEN, P (1968). Esterase, peptidase and proteinase activities of human cerebrospinal fluid in multiple sclerosis. Acta. Neurol. Scand. 44: 156-167

SCHAPIRA, F (1962). The normal aldolase activity of the CSF Clin. Chim. Acta. 7: 566-571.

SCHMUKLER, M., JEWETT, P B. and LEVY, C. C. (1975). The effects of polyamines on a residue-specific human plasma ribonuclease. J. Biol. Chem. 250: 2206-2212.

SCHRIEVER, H. and GAMBINO, S. R. (1965). Protein turbidity produced by trichloracetic acid and sulfosalicylic acid at varying temperatures and varying ratios of albumin and globulin. Amer. J Clin. Path. 44: $667-672$.

SWEET, W H., BROWNELL, G. L., SCHOOL. J A. BOWSHER, D. R., BENDA, $\mathrm{P}$ and STICKLEY, E. E. (1954). The formation, flow and absorption of cerebrospinal fluid; newer concepts based on studies with isotopes. In Neurology and Psychiatry in Childhood. Vol. XXXIV p. 101, Williams and Wilkins, Baltimore.

WAKIM, K. G. and FLEISHER, G. A. (1956). The effect of experimental cerebral infarction or transaminase activity in serum, cerebrospinal fluid and infarcted tissue. Mayo Clin. Proc. 31: 391-399.

WOLINTZ, A. H., JACOBS, L. D., CHRISTOFF, N., SOLOMON, M. and CHERNIK, N. (1969). Serum and cerebrospinal fluid enzymes in cerebrovascular disease. Creatine phosphokinase, aldolase, lactic dehydrogenase. Arch. of Neurol. 20: 54-61.

WROBLEWSKI, F, DECKER, B. and WROBLEWSKI, R. (1975). Activity of lactic dehydrogenase in spinal fluid. Amer. J. of Path. 38: 269-271.

ZIMMERMAN, S. B. and SANDEEN, G. (1965). A sensitive assay for pancreatic ribonuclease. Anal. Biochem. 10: 444-449. 